\title{
Personality-Major Congruence among the Hearing-Impaired Students in Malaysian Polytechnics
}

\author{
Samsilah Roslan ${ }^{1}$, Che'Rozaniza Azizan ${ }^{1}$, Maria Chong Abdullah ${ }^{1} \&$ Soaib Asimiran $^{1}$ \\ ${ }^{1}$ Faculty of Educational Studies, Universiti Putra Malaysia, Selangor, Malaysia \\ Correspondence: Samsilah Roslan, Department of Foundation Education, Faculty of Educational Studies, \\ Universiti Putra Malaysia, 43400 UPM Serdang, Selangor, Malaysia. Tel: 603-8946-8194. E-mail: \\ samsilah@upm.edu.my
}

Received: August 18, 2015 Accepted: August 26, 2015 Online Published: October 21, 2015

doi:10.5539/ass.v11n26p337 URL: http://dx.doi.org/10.5539/ass.v11n26p337

\begin{abstract}
Studies in the Person-Environment fit (P-E fit) framework suggested that the greater the match between students' personality types and their academic major operationalized as personality-major congruence, the more likely they are to succeed. Surprisingly to date, little research has been done on the hearing-impaired population. Thus, this preliminary analysis examined the students' personality types and the degree of personality-major congruence based on Holland's theory of vocational personalities and work environment (1997). To provide theoretical focus, gender differences in congruence measure were also investigated. Samples consisted of 26 hearing-impaired students ( $\mathrm{N}=26)$ undergoing Special Skills Certificate in 4 Polytechnics all across Malaysia. An adapted Malay version of Holland's Self Directed Search-Form E (SDS-E) was used to measure students' personality types. Findings on students' personality-major congruence were descriptively analysed and further discussed. Mann-Whitney U Test was used to analyse differences in personality-major congruence by gender. Findings indicate that gender did not play any significant roles in academic major selection among the hearing-impaired students in Malaysian Polytechnics. However, to certain degree this preliminary analysis provides general information into the largely unstudied question of how the congruence between hearing-impaired students' personality types and academic major play important role in promoting their educational outcomes. Finally, practical and theoretical considerations were also discussed.
\end{abstract}

Keywords: gender, hearing-impaired, Malaysian Polytechnics, person-environment fit, personality-major congruence

\section{Introduction}

\subsection{Widening Hearing-Impaired Accessibility: Special Skills Certificate}

Department of Polytechnic Education provides access and equity for Person with Disabilities (PWDs) in tertiary education through the establishment of Special Skills Certificate (Department of Polytechnic Education [DPE], 2012). The program involves technical and vocational training which are specialized for the hearing-impaired students. Each of the selected polytechnics offers one academic major except Politeknik Ibrahim Sultan (PIS) which offers three majors; Hotel and Catering, Apparel and Fashion Design, and Graphic Design while Politeknik Sultan Abdul Aziz Shah (PSA) and Politeknik Ungku Omar (PUO) offers Mechanical Maintenance and Civil Construction respectively. Hotel and Catering is also offered by other two polytechnics; Politeknik Tuanku Syed Sirajuddin (PTSS) and Politeknik Kota Kinabalu (PKK).

In order to widen accessibility, hearing-impaired students are given opportunities to enrol in any of the academic major regardless of their pre-entry qualifications (DPE, 2012). For graduation purposes, students are required to complete the courses in four academic semesters inclusive of one full semester of industrial training. Given such scenario, assumptions could be made that hearing impaired students would be enjoying better academic success as compared to those previous days where there were limited access and equity in tertiary education. However, DPE (2012) has stated that although there is an increase of awareness among the policy makers and stakeholders, there are still unresolved issues regarding PWDs access to tertiary education. On top of that, DPE (2012) also believes that the absence of academic major selection system may also be one of the contributing factors which lead to students' ineffectiveness. 


\subsection{Research Background}

DPE (2012) has found that hearing-impaired students in Malaysian Polytechnics have difficulties to learn effectively due to absence of academic major selection system. As result, students may choose academic major which is incongruent to their personality types due to failure in estimating their own interests and abilities. According to Holland (1997), incongruent between the students' personality types and their academic major may lead to dissatisfaction which in turn affects their academic achievements.

Studies in the Person-Environment fit (P-E fit) framework suggested that the establishment of academic major selection system may help to match the students' personality types and their academic major; thus leading to positive educational outcomes (Wong, 2006). When congruence is achieved, we believe that this would in turn promote hearing-impaired students' educational outcomes in tertiary education.

P-E fit literatures have suggested that there were plenty of research conducted to investigate the interaction between the hearing students' personality types and academic majors in tertiary education context. For example, studies have found that P-E fit correlates to academic satisfaction, major change intention, academic achievement and major persistence (Li, Yao, Chen, \& Wang, 2012; Schmitt, Oswald, Friede, Imus, \& Merritt, 2008; Tracey \& Robbins, 2006; Wessel, Ryan, \& Oswald, 2008; Westernman, Nowicki, \& Plante, 2002).

In Malaysia, P-E fit involving the hearing students at tertiary education have also been extensively studied (Azura, Mastura, Shahrani, Noor Faridatul Ainun, \& Rohizah, 2014; Hamdan, Mohamed Sharif, \& Syed Shafeq, 2004; Mastura, Ishak, \& Hamdan, 2008; Norida, Ahmad Rozelan, \& Hafzan, 2006; Wong, 2006). These studies provide important information on students' personality-major congruence and the outcome of this pairing in improving students' educational outcomes (e.g: academic satisfaction and academic achievement).

Previous studies have also suggested that gender plays important roles in the congruence measure, with male students dominating the engineering and science related fields while the females in social sciences (Gitonga, Orodho, Kigen, \& Wangeri, 2013; Gottfredson \& Holland, 1991; Smart, Feldman \& Ethington, 2000). As of this point in time, P-E fit literatures which primarily focus on the same aspect among the hearing-impaired students have yet to be found.

Thus, in order to understand the scenario, this preliminary analysis is conducted to (1) determine the hearing-impaired students' personality codes; (2) determine the hearing-impaired students' academic major codes; (3) determine the degree of personality-major congruence and (4) determine the difference between personality-major congruence and gender. This article shall begin with defining P-E fit framework in Holland Typological Approach (1997); followed by educational outcomes of personality-major congruence and finally gender differences in academic major selection. We do hope that this article may help to give a brief overview of personality-major congruence among the hearing-impaired students in Malaysian tertiary education's context as well as how P-E fit studies could be adapted to suit the needs of the students.

\section{Literature Review}

\subsection{Person-Environment Fit Theory: Holland's Typology Approach}

P-E fit theories are psychological theories (Dawis, 1992) which are also referred as the degree of congruence, match or similarity between the individual characteristics and their environment (Dawis, 1992; Edwards, Caplan, \& Harrison, 1998; Kristof, Brown, \& Guay, 2010; Schneider, Kristof, Goldstein, \& Smith, 1997). Holland's theory of vocational personalities and work environment (1997) is one of the most prominent theories in the P-E fit framework. According to Holland's Theory (Holland, 1997), individual's personality types and environment can be categorized into six types such as Realistic, Investigative, Artistic, Social, Enterprising, and Conventional (RIASEC). As been theorized, the congruence between these two may results in improved career and academic outcomes (Holland, 1997).

According to Holland (1997), each personality type is produced by interactional characteristics among variety of cultures, heredities and individual factors including peers, social class and physical environments. Through these experiences and situations, individual learn to develop their interests, which will then affect their thinking style, perception and action. Each personality type also serves as repertoire of attitudes and skills for coping with various environmental problems and tasks. In terms of perceiving or processing information, each personality type is unique in their own way, which in turn allows them to exercise their abilities, skills, and talents in order to achieve desired goals.

Holland (1997) believed that an individual's dominant personality type can be determined by comparing his attitudes with Holland's hexagonal personality model. This model also allows determination of second and third most dominant personality types. These three most dominant personality types are represented by Holland's 
3-letter codes. For example, RIA codes consisted of Realistic type, followed by Investigative and Artistic in descending order. This 3-letter code allows us to obtain a profile of resemblance which represents the complexity of personality. By using these 3-letter codes, individuals could possibly determine their best fit educational or occupational environment which may allow them to maximizing their skills, abilities and talents.

Holland (1997) also stated that each environment is dominated by a given type of personality, for example Realistic environment is mostly dominated by individuals with Realistic personality type. These people may surround themselves with those who shared common interests, dispositions, and competencies, as well as viewpoints on certain situation and problem solving. Holland (1997) believed that when these people congregate, they will create an environment that reflects their dominant personality type. This explains why an environment may be assessed in the same term as individual personality types.

Holland (1997) also highlighted that individual may search for environment which allows them to exercise their skills and abilities, express their attitudes and values, and take on agreeable problems and roles. This explains why individual with Realistic personality type feel more satisfied in Realistic environment; Investigative type will tend to search for Investigative environments, and so forth. This process is carried out in various ways at different level of consciousness over the time (Holland, 1997). Individual behaviour is also determined by interaction between personality and environment. Holland (1997) emphasized that when an individual personality-environment profile is known, the outcome of this pairing such as vocational or academic major selection, job or academic major persistence, vocational or educational achievements, personal competence, educational and social behaviours may also be predicted.

\subsection{Personality-Major Congruence and Tertiary Education's Outcomes}

In educational settings, congruence can be defined as the match between students' personality types and their academic major (Holland, 1997). Hence, in this present study, it is termed as personality-major congruence. Personality types are also regarded as strong predictors of students' academic major selection (Jones \& Jones, 2012). Studies have found that, when students choose academic major which is congruent to their personality types, the more likely they are to survive in terms of earning higher grades, persist in the chosen major, graduate on time, more academically satisfied and thus experience more success in their future career (Logue, Lounsbury, Gupta \& Leong, 2007; Porter \& Umbach, 2006). Studies also indicated that personality-major congruence is one of the main criteria which may affect students' academic achievements at tertiary level (Allen \& Robbins, 2010; Tracey, Allen, \& Robbins, 2012; Wong, 2006).

Although students may be given a chance to select their own academic major based on their interest and pre-entry qualifications, there were also cases where students were offered courses which incongruent to their personality types (Mastura et al., 2008). There were also cases where students successfully enrolled in the chosen major, but later realized that it was not as congruent as expected. This statement is in line with Stinson \& Walter (1992) who stated that hearing-impaired students failed to complete their tertiary education due to changes in career interests which are closely related to their academic major. Academic major indecision was also reported by Scherer and Walter (as cited in Lang, 2002) as the main reason of hearing-impaired students' withdrawal and changing of academic major. This explained how academic major dissatisfaction may occur which in turn affect the students' academic major persistence and their survivability in tertiary education.

In contrast, there were also cases where students easily get depressed when their academic major change application was rejected by the faculty. Like it or not, students have to force themselves to persist in the current academic major until they successfully graduated. Although there were a few of them who managed to graduate, they were less likely to be satisfied or successful in their future career (Smart et al., 2000). Their grades (CGPA) also may not be as good as their peers (Graunke \& Woosley, 2005; Tracey \& Robbins, 2006). Study by Tracey \& Robbins (2006) also found a strong positive correlation between students' personality-major congruence and overall GPA. This statement is in line with Holland (1997) who stated that students will be academically satisfied and may earn better grades if they choose academic major that matches their dominant personality types.

As discussed above, the role of personality-major congruence in ensuring students' educational outcomes are well-documented in most of P-E fit literatures involving the hearing students. However, little attention has been given on the minority groups involving PWDs at tertiary education. We believe that in promoting accessibility and equity of PWDs in technical and vocational education at tertiary level, this preliminary analysis would serves as a platform for more P-E fit studies concerning the hearing-impaired students.

\subsection{Personality-Major Congruence and Gender}

Although there are numerous of research that support Holland's typology theory, however this theory has also 
been criticized to be gender bias (Wong, 2006). This statement is in line to Holland's study on SDS which found that females scored higher on the Conventional scale as compared to males. On the other hand, males scored higher on the Realistic scale as compared to females. Gender stereotypes is said to be influenced by individual's experience and their innate potential (Holland, 1997). Despites of the critiques, his theory has the underlying properties especially in helping individuals to make decisions in term of current assets or liabilities (Brown, Brooks, \& Associates, 1990).

Smart et al., (2000) also reported gender stereotyping where science related fields and social sciences were dominated by males and females respectively. However, there are also studies that reported an increasing number of female students in engineering and other science related field, but the number is still considered small as compared to the males (Bix, 2004; Gitonga et al., 2013). The result implies that gender is one of the factors that influences academic major selection with majority of females avoiding science related field and vice versa.

Hersh (2000) also stated that female students tend to avoid subjects perceived as masculine. Females often view themselves as having weak mathematical and science abilities as compared to their male counterparts (Betz, 2005; Maimunah, 2003). Furthermore, females are normally associated with caring for people and thus are not expected to show interest nor engaged in any activities which requires more physical energy (Gitonga et al., 2013).

Cultural beliefs are considered to be a contributing factor with females preferring feminine responsibilities and males assuming roles perceived masculine (Eccles, Jacobs, \& Harold, 1990). In academic major selection, Gitonga et al. (2013) have reported gender differences where more males dominated the Realistic and Investigative fields while more females in Social scales. However, their study has found a weak correlation between gender and Artistic, Enterprising and Conventional scales.

As discussed above, it is apparent that gender differences are apparent in Holland's theory due to individual's cultural beliefs and innate potential (Holland, 1997). Although our sample size is relatively small as compared to previous studies, we do hope that this preliminary study provides an exploration of gender differences in academic major selection among the hearing-impaired students in Malaysian Polytechnics. According to Messer, Holland \& PAR Staff (2013), Hotel and Catering is categorized as Realistic, Graphic Design is Artistic and Civil Construction is Investigative in nature.

As been theorized, we expect more males would be in Hotel and Catering, followed by Civil Construction and Graphic Design majors. However, emerging findings on these gender differences may also be taken into consideration as the ratio of male and female students is imbalanced especially in Civil Construction where more females were assigned to the field as compared to male students. Despite of these limitations, we strongly believed that our findings may show some important contributions so that further studies could be done to provide better understanding on academic major selection among the hearing-impaired students in tertiary education.

\section{Methodology}

This study involved a descriptive quantitative survey to measure the congruence between the hearing-impaired students' personality types and their academic majors in Malaysian Polytechnics. Respondents consisted of 26 hearing-impaired students' of second and fourth semester (June 2014 intake) from four Polytechnics all across Malaysia. Students' personality types were assessed by using an adapted version of Self Directed Search-Form Easy (Holland, 1996) $(\mathrm{R}=0.921)$. This instrument consisted of 2-way closed-ended questions (Yes/No). Although the framework of the study is adapted from the hearing population, extra precautions were given in selecting the instrument for the study. This is to ensure that all of the items could be easily understood by the respondents.

Since this study involved hearing-impaired students who have limited reading abilities as compared to their hearing peers (Hallahan \& Kauffman, 2000), we have decided to use Holland's SDS-E which is specially design for individual with limited reading abilities (Holland, Fritzsche, \& Powell, 1997). On top of that, a few items were modified to accommodate the respondents reading ability. In addition, picture booklet was also provided to give graphical explanation on selected items. Sign-language interpreter and individual assistance were also provided during data collection to accommodate students' special needs.

Academic major codes were determined by using Educational Opportunities Finder $^{\mathrm{TM}}$ (EOF) by Messer et al. (2013). Personality-major congruence was then identified by using Iachan's index (1984, 1990). The personality and academic major (environment) codes represented the 3 most dominant types in the RIASEC scale.

Descriptive and inferential statistics were used to analyse all the research data. Descriptive analyses include frequencies, percentage and mean to explain the respondents' demographic factors, personality types and the 
degree of personality-major congruence. The research questions are as follows:

i) What is the hearing-impaired students' personality code?

ii) What is the hearing-impaired students' academic major code?

iii) What is the hearing-impaired students' degree of personality-major congruence?

For inferential analysis, Mann Whitney U Test was used to analyse the difference between the students' degree of personality-major congruence and gender. The research hypothesis is formulated as follows:

There is no significant gender difference in the personality-major congruence scores.

\section{Findings}

\subsection{Respondents' Demographic Factors}

Descriptive analysis in Table 1 shows that there is only a slight difference between the female $(\mathrm{N}=14 ; 53.8 \%)$ and the male respondents $(\mathrm{N}=12 ; 46.2 \%)$. Malay respondents $(\mathrm{N}=14 ; 53.8 \%)$ dominates the analysis, followed by Chinese $(\mathrm{N}=7 ; 27.0 \%)$, others $(\mathrm{N}=4 ; 15.5 \%)$ and lastly Indian $(\mathrm{N}=1 ; 3.8 \%)$. Majority of the respondents age between 21 to 22 years old $(\mathrm{N}=14,53.8 \%)$, followed by 19 to 20 years old $(\mathrm{N}=11 ; 42.4 \%)$ and the eldest is 31 years old $(\mathrm{N}=1 ; 3.8 \%)$. Hotel and Catering had the highest number of respondents $(\mathrm{N}=13 ; 50 \%)$, followed by Civil Construction $(\mathrm{N}=8 ; 30.8 \%)$ and Graphic Design $(\mathrm{N}=5 ; 19.2 \%)$.

Table 1. Demographic analysis

\begin{tabular}{cccc}
\hline & Sample Characteristics & Frequency & Percentage (\%) \\
\hline \multirow{2}{*}{ Gender } & Males & 12 & 46.2 \\
& Females & 14 & 53.8 \\
& Malay & 14 & 53.8 \\
Race & Chinese & 7 & 27.0 \\
& Indian & 1 & 3.8 \\
& Others & 4 & 15.4 \\
Age & 19-20 years old & 11 & 42.4 \\
& 21- 22 years old & 14 & 53.8 \\
Academic Major & $>23$ years old & 1 & 3.8 \\
& Graphic Design & 5 & 19.2 \\
& Hotel and Catering & 13 & 50.0 \\
\hline
\end{tabular}

\subsection{Personality Codes}

Table 2 shows respondents' personality codes which are obtained by summated means of the three most dominant personality codes. For Graphic Design, the highest score is Artistic personality types $(\mathrm{M}=5.40)$, followed by Social $(M=4.20)$ and Enterprising $(M=4.0)$. For Hotel and Catering, the highest score is Social personality types $(\mathrm{M}=4.60)$, followed by Realistic $(\mathrm{M}=4.23)$ and Artistic $(\mathrm{M}=3.54)$. Finally, for Civil Construction, the highest score is Social personality types $(M=4.50)$, followed by Realistic $(M=3.88)$ and Conventional $(\mathrm{M}=3.38)$. The analysis concludes that the personality code for Graphic Design is ASE, Hotel and Catering is SRA and Civil Construction is SRC.

Table 2. Personality codes analysis

\begin{tabular}{|c|c|c|c|c|c|c|c|c|}
\hline \multirow{2}{*}{ No } & \multirow{2}{*}{ Academic Major } & \multicolumn{6}{|c|}{ Mean } & \multirow{2}{*}{$\begin{array}{c}\text { Personality } \\
\text { Code }\end{array}$} \\
\hline & & $\mathrm{R}$ & $\mathrm{I}$ & A & $\mathrm{S}$ & $\mathrm{E}$ & $\mathrm{C}$ & \\
\hline 1. & Graphic Design & 2.20 & 2.40 & 5.40 & 4.20 & 4.0 & 2.80 & ASE \\
\hline 2. & Hotel \& Catering & 4.23 & 2.77 & 3.54 & 4.60 & 2.77 & 3.00 & SRA \\
\hline 3. & Civil Construction & 3.88 & 2.75 & 2.50 & 4.50 & 3.50 & 3.38 & $\mathrm{SRC}$ \\
\hline
\end{tabular}

Note. $\mathrm{R}=$ Realistic, $\mathrm{I}=$ Investigative, $\mathrm{A}=$ Artistic, $\mathrm{S}=$ Social, $\mathrm{E}=$ Enterprising, $\mathrm{C}=$ Conventional.

\subsection{Academic Major Codes}

Table 3 shows three academic major codes in Polytechnic as obtained from the EOF (Messer et. al., 2013). Academic major code for Graphic Design is AES, Hotel and Catering is RAS and Civil Construction is IER. 
Table 3. Academic major codes

\begin{tabular}{ccc}
\hline No. & Academic Major & Academic Major Code \\
\hline 1. & Graphic Design & AES \\
2. & Hotel \& Catering & RAS \\
3. & Civil Construction & IER \\
\hline
\end{tabular}

\subsection{Degree of Personality-Major Congruence}

Table 4 shows degree of personality-major congruence analysis among the hearing-impaired students in three academic majors in Polytechnics. Graphic Design shows the highest degree of congruence and thus indicates a good match between the students' personality types and their academic major. In contrast, Civil Construction has the lowest degree of congruence which indicates a poor match between the students' personality types and their academic major. Hotel and Catering which consists of PKK and PTSS students have low to moderate degree of congruence which indicates a not close match between the students' personality types and their academic major.

Table 4. Degree of personality-major congruence

\begin{tabular}{ccccc}
\hline No. & Personality Code & Academic Major Code & Degree of Congruence & Level of Congruence \\
\hline 1 & ASE & AES & 26 & Good Match \\
2 & SRA & RAS & 16 & Not Close Match \\
3 & SRC & IER & 4 & Poor match \\
\hline
\end{tabular}

\subsection{Differences of Personality-Major Congruence by Gender}

A Mann-Whitney $U$ test was run to determine if there were differences in degree of personality-major congruence between male and female students in each of the academic major. Distribution of the personality-major congruence scores for males and females in Graphic Design, Hotel \& Catering and Civil Construction were not similar, as assessed by visual inspection. For Graphic Design, Table 5 shows that personality-major congruence for male students (mean rank $=2.83$ ) and female students $($ mean rank $=3.25)$ were not statistically significantly different $(\mathrm{U}=2.500, \mathrm{z}=-.296, \mathrm{p}=.767)$. For Hotel \& Catering, personality-major congruence for male students (mean rank $=6.31$ ) and female students (mean rank $=8.10$ ) were not statistically significantly different $(\mathrm{U}=14.500, \mathrm{z}=-.812, \mathrm{p}=.417)$. Finally, personality-major congruence for male students (mean rank $=2.00$ ) and female students (mean rank $=4.86$ ) in Civil Construction were not statistically significantly different $(U=1.00, z=-1.104, p=.269)$. Since all the $p$-values are $>.05$, we failed to reject the null hypothesis. Thus, there is enough evidence to conclude that the personality-major congruence scores between males and females are equal.

Table 5. Differences of personality-major congruence by gender

\begin{tabular}{ccccccccc}
\hline \multirow{2}{*}{ Academic Majors } & \multicolumn{3}{c}{ Males } & \multicolumn{2}{c}{ Females } & & \multirow{2}{*}{$\mathrm{Z}$} & $\mathrm{p}$ \\
\cline { 2 - 6 } & $\mathrm{n}$ & Mean Rank & $\mathrm{n}$ & Mean Rank & & & & \\
\hline Graphic Design & 3 & 2.83 & 2 & 3.25 & & 2.500 & -.296 & .767 \\
Hotel \& Catering & 8 & 6.31 & 5 & 8.10 & & 14.500 & -.812 & .417 \\
Civil Construction & 1 & 2.00 & 7 & 4.86 & & 1.000 & -1.104 & .269 \\
\hline
\end{tabular}

$\mathrm{p}<0.05$

\section{Discussions}

From the findings, Graphic Design is mainly dominated by Artistic personality, followed by Social and Enterprising personality types. Although there is a slight change in the second and third letter's order (i.e ASE instead of AES), this result indicates that the personality-major congruence is achieved. In other words, the hearing-impaired students' personality type fits their academic major. The result also implies that Graphic Design students expressed themselves as imaginative, idealistic, values aesthetics and creation of art forms, impulsive, independent, values social, ambitious, energetic, religious, aggressive, leadership skills, self-confident and sociable (Holland, 1997).

These characteristics are in line with Holland (1997) third assumptions which stated that students will search for 
environment that allows them to exercise their skills and abilities, express their attitudes and values, and take on agreeable problems and roles. As result, academic major satisfaction is achieved which may in turn affect their academic major persistence and academic success (Nye, Su, Rounds, \& Drasgow, 2012). Allen \& Robbins (2008) also found a large effect of personality-major congruence on major change intention.

On the other hand, both Civil Construction and Hotel and Catering show contradictory findings as compared to Graphic Design. The first and second environmental codes for both academic majors were made up of Social and Realistic types. This implies that, students from both academic majors perceived themselves as having interests in educational activities, concern with social problems, believe in equality, helpful, forgiving, religious, having mechanical, technical, and athletic abilities and love to work with people as well as machines or instruments (Holland, 1997). Realistic personality type also appears to be among the three most dominant codes in both academic majors as students mainly exercise their realistic skills and abilities in the training and practical sessions, workshops or industrial training.

Findings for both Civil Construction and Hotel and Catering implies that students' personality types showed lower congruency with their academic major as compared to Graphic Design. According to Holland (1997), the mismatch between the students' personality and academic major may lead to academic dissatisfaction. This will eventually affect their academic achievements as well as their future career path, as the academic major selection will directly impact students' future career selection (Wong, 2006).

The mean analysis of the RIASEC scales also found that Social personality type was among the three most dominant scales for all the academic majors (Table 2). This finding is also in line to Hamdan et al., (2004) who found Social personality type being the most dominant types in almost all 60 academic majors under study. This current study implies that possibly majority of the hearing-impaired students of different personality types may choose an academic major with one substantial Social component in his or her personality.

Albeit the small sample size, this study also attempted to analyse any significant gender differences in the congruence measure. The hypothesis testing of gender differences for all the three academic majors showed that there were no significant differences among the male and female students' personalities. This could be explained by disproportional distributions between male and female students as shown in Table 5. For example, Civil Construction which is regarded as Investigative environment in nature (Messer et al., 2013) was mainly dominated by female in 7:1 ratio as compared to male.

Previous studies have reported that more males were found in Investigative majors who require more scientific abilities as compared to females (Gitonga et al., 2013; Ranson, 2003; Smart et al., 2000). We believe that unequal distribution of enrolment between male and female students in Polytechnics might be partly due to absence of establish academic major selection system. Although hearing-impaired students in Polytechnics were given opportunities to select their own academic major, the final decision is still subjected to panels' discretion (DPE, 2012). Furthermore, the absence of academic major selection system is said to be one of the factors leading to students' failure in estimating their own interest and abilities (St. John, 2000; Wong, 2006).

Although our findings on gender differences contradicted several studies (e.g Gitonga et al., 2013; Haliburton, Thweatt, \& Wahl, 1998; Thompson, Donnay, Morris, \& Schaubhut, 2004), but it is in line to Hamdan Abdul Kadir et al., (2004) who found insignificant gender differences in 49 out of 60 courses including those under Civil Engineering faculty. Cultural differences may partly explain this situation, but we strongly believe that gender differences would be significantly apparent if larger samples were introduced; thus leading to more valid and significant result.

\section{Conclusion}

This research may be subjected to limitations as previously discussed. However, it does in certain degree contribute to the understanding of Holland's typology in the selection of academic major among the hearing-impaired students in Malaysian Polytechnics. The findings imply that students may experience difficulties in choosing their academic majors due to multiple interests in multiple field of study or they simply have no preferences for any field of study (Amir Awang, 1983). As a result, they may choose academic major which is incongruent to their personality types. This is known as academic major indecision which refers to students' failure in estimating their own interests and abilities (Wong, 2006).

This scenario is worrisome and requires urgent attention especially when special population groups are involved; e.g the hearing-impaired students. Studies indicate that, although hearing-impaired students' have normal cognitive abilities, their academic achievements are lagging far behind than their peers of the same age and academic level (Akinpelu, 1998; Antia, Jones, Reed, \& Kreimeyer, 2009; Lang, 2002; Qi \& Mitchell, 2012). 
There are many contributing factors leading to academic achievements and other educational outcomes which are specific for the hearing-impaired population (e.g: degree of hearing loss, the use of hearing aid, early intervention and etc.). However, limited focus has been given on the P-E fit context.

Thus, the findings of this study provide general information on the importance of personality-major congruence in ensuring hearing-impaired educational outcomes at tertiary level. Thus by implementing P-E fit framework, a more extensive study could be done to provide empirical information on the factors that contributes to hearing-impaired students' outcomes at tertiary level. Emphasis should be given on personality-major congruence since Holland (1997) believes that the congruence between these two may contribute to educational satisfaction and academic achievements.

Hence, educational authorities especially the Department of Polytechnic Education should also consider the establishment of specialized academic major selection system in addressing the issues of personality and academic major mismatch. This allows for more scientific and systematic way of choosing an academic major; thus leading to positive students' outcome. Counsellor intervention is also expected to provide effective career planning, followed by proper intervention to suit the educational needs of the hearing-impaired students.

\section{References}

Akinpelu, O. F. (1998). A study of the academic achievement and self-concept of male and female hearing-impaired students in Nigeria. The Nigerian Journal of Guidance and Counselling, 6(1\&2), 1-10. http://dx.doi.org/10.4314/njgc.v6i1.37085

Allen, J., \& Robbins, S. (2008). Prediction of college major persistence based on vocational interests and firstyear academic performance. Research in Higher Education, 49(1), 62-79. http://dx.doi.org/10.1007/ s11162-007-9064-5

Allen, J., \& Robbins, S. (2010). Effects of interest-major congruence, motivation, and academic performance on timely degree attainment. Journal of Counseling Psychology, 57(1), 23-35. http://dx.doi.org/10.1037/ a0017267

Antia, S. D., Jones, P. B., Reed, S., \& Kreimeyer, K. H. (2009). Academic status and progress of deaf and hard-of-hearing students in general education classrooms. Journal of Deaf Studies and Deaf Education, 14(3), 293-311. http://dx.doi.org/10.1093/deafed/enp009

Awang, A. (1983). Bimbingan dan kounseling untuk kesejaheraan masyarakat. Jurnal Perkama, 1, 1-12.

Betz, N. E. (2005). Measuring confidence for basic domains of vocational activity in high school students. Journal of Career Assessment, 13(3), 251-270. http://dx.doi.org/10.1177/1069072705274951

Bix, S. A. (2004). From Engineers to "girl engineers" to "good engineers": A history of women's US Engineering Education. National Women's Study Association Journal, 16(1), 27-49. http://dx.doi.org/10.1353/nwsa.2004.0028

Brown, D., Brooks, L., \& Associates. (1990). Career choice and development. San Francisco: Jossey-Bass Publishers.

Dawis, R. V. (1992). Person-environment fit and job satisfaction. In C. J. Cranny, P. C. Smith, \& E. F. Stone (Eds.), Job satisfaction: How people feel about their jobs and how it affects their performance. New York, NY: Lexington Books.

Department of Polytechnic Education. (2012). Dasar pengajian pelajar kurang upaya di Politeknik dan Kolej Komuniti bagi peluasan akses dan peningkatan ekuiti (Policy research). Policy Development Division, Putrajaya: Department of Polytechnic Education.

Eccles, J. S., Jacobs, J. E., \& Harold, R. D. (1990), Gender Role Stereotypes, Expectancy Effects, and Parents' Socialization of Gender Differences. Journal of Social Issues, 46, 183-201. http://dx.doi.org/10.1111/j. 1540-4560.1990.tb01929.x

Edwards, J. R., Caplan, R. D., \& Harrison, R. V. (1998). Person-environment fit theory: Conceptual foundations, empirical evidence, and directions for future research. In C. L. Cooper (Ed.), Theories of organizational stress. Oxford, UK: Oxford University.

Gitonga, C., Orodho, J., Kigen, W., \& Wangeri, T. (2013). Gender differences in Holland. International Journal of Education and Research, 1(7), 1-10. Retrieved September 7, 2015, from http://www.ijern.com/ journal/July-2013/24.pdf

Gottfredson, G. D., \& Holland, J. L. (1991). Position classification inventory professional manual. Odessa FL: 
Psychological Assessment Resources, Inc.

Graunke, S. S., \& Woosley, S. A. (2005). An exploration of the factors that affect the academic success of college sophomores. College Student Journal, 39, 367-376.

Haliburton, W., Thweatt, M., \& Wahl, N. J. (1998). Gender differences in personality components of computer science students: a test of Holland's congruence hypothesis. ACM SIGCSE Bulletin, 30(1), 77-81. http://dx.doi.org/10.1080/10641269309388546

Hallahan, D. P., \& Kauffman, J. M. (2000). Exceptional learners: Introduction to special education (8th ed.). Needham Heights: Allyn \& Bacon.

Hamdan, A. K., Mohamed Sharif, M., \& Syed Shafeq, S. M. A. H. (2004). Pola personaliti-persekitaran (p-e fit) dan perbandingan kongruen personaliti persekitaran (eat) pelajar Universiti Teknologi Malaysia, Skudai (unpublished). Universiti Teknologi Malaysia.

Hersh, M. (2000). The changing position of women engineering worldwide. IEEE Transaction of Engineering Management, 47(3), 345-59. http://dx.doi.org/10.1109/17.865903

Holland, J. L. (1996). Self-Directed Search ${ }^{\circledR}-$ Form E (4th ed.). Lutz, Florida: Psychological Assessment Resource Inc.

Holland, J. L. (1997). Making vocational choices: A theory of vocational personalities and work environments (3rd ed.). Florida: Psychological Assessment Resources.

Holland, J. L., Fritzsche, B. A., \& Powell, A. B. (1997). Self-Directed Search: Technical Manual. Lutz, Florida: Psychological Assessment Resource Inc.

Iachan, R. (1984). A measure of agreement for use with the Holland classification system. Journal of Vocational Behaviour, 24, 133-141. http://dx.doi.org/10.1016/0001-8791(84)90001-0

Iachan, R. (1990). Some extensions of the Iachan congruence index. Journal of Vocational Behaviour, 36, 176-180. http://dx.doi.org/10.1016/0001-8791(90)90025-W

Ishak, A., Rahmat, M., Shahrani, S., Zainal, N. F. A., \& Rahman, R. A. (2014). Keselarasan personaliti dengan pemilihan program sains komputer dan teknologi maklumat. Jurnal Teknologi (Sciences and Engineering), 68(1), 49-55. http://dx.doi.org/10.11113/jt.v68.1831

Jones, L. K., \& Jones, J. W. (2012). A guide for professionals helping youth and adults who are in college or are college-bound. Career Key, Inc. Retrieved May 20, 2014, from www.careerkey.org

Kristof-Brown, A. L., \& Guay, R. P. (2010). Person-environment fit. In S. Zedeck (Ed.), APA Handbook of Industrial and Organizational Psychology. Washington, DC: American Psychological Association.

Lang, H. G. (2002). Higher education for deaf students. Research Priorities in the New Millennium, 4(7), 267-280.

Li, Y., Yao, X., Chen, K., \& Wang, Y. (2012). Different fit perceptions in an academic environment: Attitudinal and behavioral outcomes. Journal of Career Assessment, 21(2), 163-174. http://dx.doi.org10.1177/ 1069072712466713

Logue, C. T., Lounsbury, J. W., Gupta, A., \& Leong, F. T. L. (2007). Vocational interest themes and personality traits in relation to college major satisfaction of business students. Journal of Career Development, 33, 269-295.

Maimunah, I. (2003). Men and women engineers in a large industrial organization: Interpretation of career progression based on subjective career experiences. Women in Management Review, 18(1/2), 60-67. http://dx.doi.org/10.1108/09649420310462334

Mastura, M., Ishak, M. S., \& Hamdan, A. K. (2008). Kekongruenan personaliti-persekitaran kursus dan hubungannya dengan pencapaian akademik di kalangan pelajar. Jurnal Kemanusiaan, 12, 23-32.

Messer, M. A., Holland, J. L., \& PAR Staff. (2013). The educational opportunities finder ${ }^{\mathrm{TM}}$. Lutz, FL: PAR Inc.

Norida, A., Ahmad Rozelan, Y., \& Hafzan, A. (2006). Keselarasan personaliti dengan program pengajian dan hubungannya dengan pencapaian akademik pelajar KUTKM (unpublished). Kolej Universiti Teknikal Kebangsaan Malaysia.

Nye, C. D., Su, R., Rounds, J., \& Drasgow, F. (2012). Vocational interests and performance: A quantitative summary of over 60 years of research. Perspectives on Psychological Science, 7(4), 384-403. 
http://dx.doi.org/10.1177/1745691612449021

Porter, S. R., \& Umbach, P. D. (2006). College major choice: An analysis of person- environment fit. Research in Higher Education, 47(4), 429-449. http://dx.doi.org /10.1007/s11162-005-9002-3

Qi, S., \& Mitchell, R. E. (2012). Large-scale academic achievement testing of deaf and hard-of-hearing students: Past, present, and future. Journal of Deaf Studies and Deaf Education, 17(1), 1-18. http://dx.doi.org/10.1093/deafed/enr028

Ranson, G. (2003). Beyond gender differences: A Canadian study of women and men careers in engineering. Gender, Work and Organisation, 10(1), 22-41.

Scherer, M. J., \& Walter, G. (1988). Student-reported satisfaction with college and reasons for college withdrawal (Technical Report). Rochester, NY: Rochester Institute of Technology. In Lang, H. G.. Higher education for deaf students. Research Priorities in the New Millennium, 4(7), 267-280.

Schmitt, N., Oswald, F. L., Friede, A., Imus, A., \& Merritt, S. (2008). Perceived fit with an academic environment: Attitudinal and behavioral outcomes. Journal of Vocational Behavior, 72(3), 317-335. http://dx.doi.org/10.1016/j.jvb.2007.10.007

Schneider, B., Kristof, B. A., Goldstein, H. W., \& Smith, D. B. (1997). What is this thing called fit. In N. Anderson, \& P. Herriot (Eds.), International Handbook of Selection and Assessment. New York, NY: Wiley.

Smart, J. C., Feldman, K. A., \& Ethington, C. A. (2000). Academic disciplines: Holland's theory and the study of college students and faculty. Nashville, TN: Vanderbilt University Press.

St. John, E. (2000). Do major matter.? Black Issue in Higher Education, 17(4), 3-4.

Stinson, M. S., \& Walter, G. G. (1992). Persistence in college. In S. B. Foster, \& G. G. Walter (Eds.), Deaf students in postsecondary education. New York: Routledge.

Thompson, R. C., Donnay, D. A. C., Morris, M. L., \& Schaubhut, N. A. (2004). Exploring Age and Gender Differences in Vocational Interests. Annual Convention of the American Psychological Association, Honolulu, HI, 1-11.

Tracey, T. J. G., \& Robbins, S. B. (2006). The interest-major congruence and college success relation: A longitudinal study. Journal of Vocational Behavior, 69, 64-89. http://dx.doi.org /10.1016/j.jvb.2005.11.003

Tracey, T. J. G., Allen, J., \& Robbins, S. B. (2012). Moderation of the relation between person-environment congruence and academic success: environmental constraint, personal flexibility and method. Journal of Vocational Behavior, 80(1), 38-49. http://dx.doi.org /10.1016/j.jvb.2011.03.005

Wessel, J. L., Ryan, A. M., \& Oswald, F. L. (2008). The relationship between objective and perceived fit with academic major, adaptability, and major-related outcomes. Journal of Vocational Behavior, 72(3), 363-376. http://dx.doi.org/10.1016/j.jvb.2007.11.003

Westernman, J. W., Nowicki, M. D., \& Plante, D. (2002). Fit in the classroom: predictors of student performance and satisfaction management education. Journal of Management Education, 26(1), 5-18. http://dx.doi.org/10.1177/105256290202600102

Wong, K. F. (2006). A career guidance software for selection of college majors in Universiti Putra Malaysia (unpublished doctoral thesis). Universiti Putra Malaysia, Serdang.

\section{Copyrights}

Copyright for this article is retained by the author (s), with first publication rights granted to the journal.

This is an open-access article distributed under the terms and conditions of the Creative Commons Attribution license (http://creativecommons.org/licenses/by/3.0/). 